\title{
Denitrifying bacteria in the limnetic zone of Lake Tota, Colombia
}

\author{
Julián Esteban Másmela-Mendoza*1, Luz Marina Lizarazo-Forero ${ }^{1}$
}

\section{Edited by}

Juan Carlos Salcedo-Reyes

salcedo.juan@javeriana.edu.co

1. Universidad Pedagógica y Tecnológica de Colombia, Facultad de Ciencias, Departamento de Biología, Grupo de Investigación Biología Ambiental, Avenida Central del Norte 39-115, Boyacá, Colombia, 150003

*bio.ambient@uptc.edu.co

Received: $13-01-2020$

Accepted: 18-01-2021

Published online: 27-05-2021

Citation: Másmela-Mendoza JE, Lizarazo-Forero LM. Denitrifying bacteria in the limnetic zone of Lake Tota,

Colombia, Universitas Scientiarum, 26

(1): 1-16, 2021.

doi: 10.11144/Javeriana.SC26-1.dbit

Funding: Capital Semilla No. 1, 2015, from the Research Directorate (DIN) at Universidad Pedagógica y Tecnológica de Colombia - UPTC.

Electronic supplementary material: Supp. 1

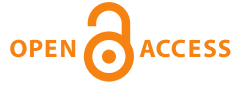

\begin{abstract}
The objective of study was to isolate and determine the identity of denitrifying bacteria from limnetic areas of Lake Tota (Colombian Andes) with and without rainbow trout production activities. We examined the relationships between the lake's physicochemical factors (oxygen, nitrogen, and phosphorus content) and two bacterial communities (denitrifying bacteria and coliforms). Water samples were taken $20 \mathrm{~m}$ below the surface from July to September at five limnetic zones; two of which were close to rainbow trout farming areas. In each zone, the concentrations of oxygen, nitrogen, and phosphorus were measured. To identify and quantify the abundance of bacteria, the most probable number (MPN) technique was used, employing minimal medium for denitrifying bacteria and medium for nitrate reducing bacteria (NRB). A greater number of denitrifying bacteria were found in the fish farming zones, identifying bacteria of the genera Bacillus, Pseudomonas, Nocardia, and Streptomyces. The number of nitrate-reducing bacteria revealed statistically significant differences throughout the sampling period, increasing from July to September and was related to a decrease in precipitation. The density of NRB and total phosphorus were directly correlated. High bacterial densities of denitrifying bacteria and coliforms are indicative of changes from oligotrophic to eutrophic states in the studied limnetic areas.
\end{abstract}

Keywords: Denitrifying bacteria; eutrophication; fish farms; freshwater lakes; water pollution.

\section{Introduction}

The changes in oxidation and reduction of nitrogen $(\mathrm{N})$ in the water column and sediments of a freshwater lake are mainly produced by microbial communities specialized in the use of this nutrient [1] Among these microorganisms, denitrifying bacteria [2, 3] fulfill the ecological function of reducing nitrates $\left(\mathrm{NO}_{3}^{-}\right)$to nitrogen gas $\left(\mathrm{N}_{2}\right)$, which returns to the atmosphere, contributing to the chemical balance of nitrogen in freshwater aquatic ecosystems $[4,5,6]$.

Denitrification is the sequential reduction of oxidized $\mathrm{N}$ compounds $\left(\mathrm{NO}_{3}\right.$ and $\left.\mathrm{NO}_{2}\right)$ to gaseous end products $\left(\mathrm{NO}, \mathrm{N}_{2} \mathrm{O}\right.$, and $\left.\mathrm{N}_{2}\right)[2,7]$, whereby nitrogen gas $\left(\mathrm{N}_{2}\right)$ can be released into the atmosphere or diffused into the water column [1] Denitrifying microorganisms are chemoorganotrophs; these are generally facultative anaerobic bacteria, but can also be found within a wide range of taxonomically distinct groups of Bacteria and Archaea.

Denitrifying bacteria include representative cultivable species such as Pseudomonas, Bacillus, Streptomyces, Frankia, Nocardia, Paracoccus, Alcaligenes, and Thiobacillus among others [7]. The physicochemical factors that influence the metabolism and distribution of denitrifying 
microbial populations include dissolved oxygen, nitrate concentration, and organic matter $[1,2,6]$. However, it has been documented that some bacteria do not complete the process, in some cases, they only reduce nitrogen to nitrites, nitrous, or nitric oxides [7].

Lake Tota, located in the department of Boyacá in Colombia is the most important freshwater ecosystem of the Colombian Andes. It is classified as oligotrophic; however, various activities developed near the littoral zone, such as the dumping of sewage from neighboring municipalities, the use of pesticides and fertilizers from agricultural work, and the farming of rainbow trout are generating an increase in nutrient concentrations that affect the environmental quality of this freshwater ecosystem $[8,9]$.

The intense development of the aquaculture industry can cause ecological damage by increasing the nutrient content which is mainly carbon, nitrogen, and phosphorus from fish excrement, evisceration products, and leftover fish food. These accumulate in the bottom of the lake, altering the trophic state of ecosystem $[10,11,12]$. It has been documented that denitrifying bacteria participate by mineralizing detritus and regulating nitrate concentrations in lakes where fish are farmed $[4,10,11,13]$.

The purpose of this study was to examine the relationships between Lake Tota's physicochemical factors (including $\mathrm{pH}$, alkalinity, dissolved oxygen, oxygen saturation, and electric conductivity) nitrogen, phosphorus, and the cultivable bacterial community (cultivable denitrifying bacteria and coliforms) and to provide information for the protection and control of pollution in Lake Tota, in Boyacá, Colombia.

\section{Materials and methods}

\subsection{Study site}

Lake Tota is located on the eastern Colombian mountain range, in the department of Boyacá between $5^{\circ} 28^{\prime} \mathrm{N}$ to $5^{\circ} 39^{\prime} \mathrm{N}$ and $72^{\circ} 51^{\prime} \mathrm{W}$ [9]. It has an area of $60 \mathrm{~km}^{2}$, with an average depth of $30 \mathrm{~m}$ and an average temperature of $11^{\circ} \mathrm{C}$. The weather pattern for the lake's basin is unimodal, with a dry period from December to March and a rainy period from April to November. It is a polymictic system, with high concentrations of dissolved oxygen and a neutral $\mathrm{pH}$ with tendency towards basic [14].

\subsection{Sampling areas}

Five areas were defined in the limnetic zone of the lake as described in Table $\mathbf{1}$ and as shown in Figure 1.

Table 1: Sampling areas for Lake Tota in Boyacá, Colombia.

\begin{tabular}{llll}
\hline & \multicolumn{2}{c}{ Limnetic zone } & \multicolumn{2}{c}{ Coordinates } \\
\hline 1 & Lago Chico Center & $5^{\circ} 32^{\prime} \mathrm{N}$ & $72^{\circ} 53^{\prime} \mathrm{W}$ \\
2 & Lago Chico Custodia & $5^{\circ} 30^{\prime} \mathrm{N}$ & $72^{\circ} 54^{\prime} \mathrm{W}$ \\
3 & Lago Grande Center & $5^{\circ} 32^{\prime} \mathrm{N}$ & $72^{\circ} 55^{\prime} \mathrm{W}$ \\
4 & Lago Grande Rainbow trout farm-Hato Laguna & $5^{\circ} 34^{\prime} \mathrm{N}$ & $72^{\circ} 54^{\prime} \mathrm{W}$ \\
5 & Lago Grande Rainbow trout farm-El Túnel & $5^{\circ} 33^{\prime} \mathrm{N}$ & $72^{\circ} 56^{\prime} \mathrm{W}$ \\
\hline
\end{tabular}




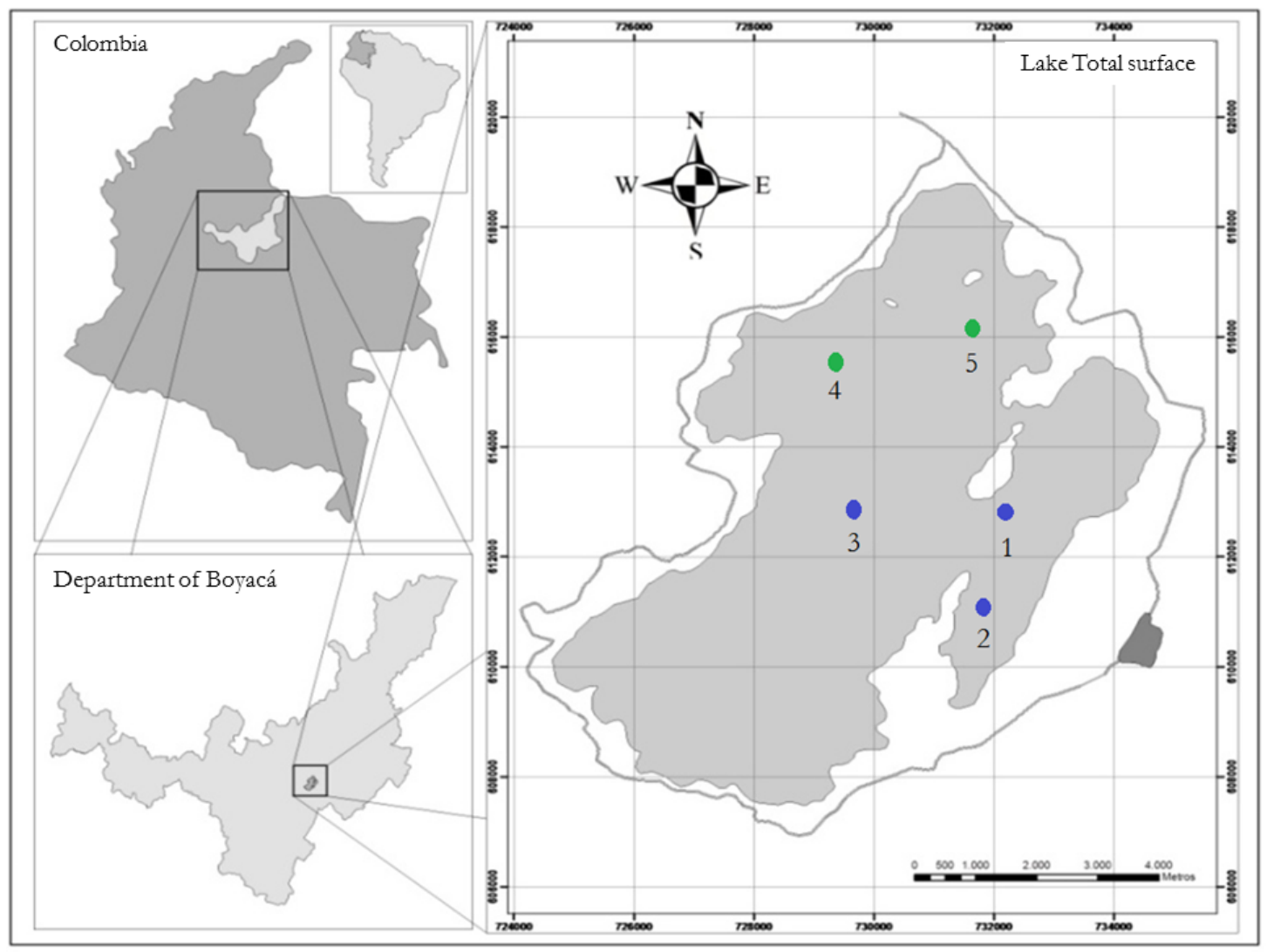

Figure 1: Sample areas of Lake Tota in Boyacá, Colombia. Green dots indicate sampled areas affected by the farming of rainbow trout. Blue dots mark sampling areas in central limnetic areas.

\subsection{Sampling}

For each area samples of the water column were taken at an approximate depth of $20 \mathrm{~m}$ for the analysis of aerobic denitrifying bacteria. This depth is close to the sediment layer in most zones. Samples $(n=4)$ for microbiological and physicochemical analyses were taken from July to September 2015. Samples taken in July correspond to the rainy period and samples taken in September correspond to the low rainfall period. Four water samples were taken per site; two samples in the rainy season (July) and two samples in the dry season (August and September). The samples were taken from the five zones described in Figure 1.

Samples were taken with a horizontal sampling bottle (Wildco Wildlife Supply Company, USA) and kept in sterile glass containers of $1 \mathrm{~L}$, and preserved in dry ice until processing within $12 \mathrm{~h}$. In-between samplings, the bottle was rinsed with $1 \mathrm{M} \mathrm{HCl}$ and sterile distilled water.

\subsection{In situ measurement of physicochemical variables}

Water $\mathrm{pH}$ and temperature were recorded at each sampling location using a Schott instruments D55014 Mainz pH meter (Germany); alkalinity and total hardness were assessed using colorimetric kits (Merck, Germany); dissolved oxygen (DO) and oxygen saturation were measured with a YSI model 55/12 FT oximeter (YSI Inc., USA) (Add producer's name and country); and electrical conductivity was measured with a YSI model 85 conductivity device (YSI Inc., USA). 


\subsection{Concentrations of nitrogen and phosphorus}

To separate the organic and inorganic layers from total nutrients, $1 \mathrm{~L}$ of water was filtered through $0.45 \mu \mathrm{m}$ nitrocellulose membranes, and the chemical technique of digestion with persulfate was used to measure total nitrogen, dissolved inorganic nitrogen, total phosphorus, and dissolved phosphorus [15].

\subsection{Most probable number of denitrifying bacteria}

The Most Probable Number - MPN technique is a procedure whereby bacterial isolates of a water or soil sample are cultivated to assess densities. With this approach, an approximate number of the cultured bacteria in the source of the isolates can be estimated. Furthermore, the presence or absence of a bacterial population is determined via replicates of consecutive dilutions of the initial culture. Minimal medium (Suppl. 1) [16] was used to isolate and quantify, via the MPN technique, denitrifying bacteria from Lake Tota capable of forming ammonium and / or nitrites from nitrates.

The MPN procedure is described as follows: All of the $1000 \mathrm{~mL}$ water samples were prehomogenized and employed in serial dilutions $\left(1 \times 10^{-1}, 1 \times 10^{-2}, 1 \times 10^{-3}, 1 \times 10^{-4}\right.$, and $1 \times 10^{-5}$ ). Of each dilution, $1 \mathrm{ml}$ was allocated in tubes with $9 \mathrm{~mL}$ of minimal medium. Five replicates were done per dilution. The tubes were incubated at $30^{\circ} \mathrm{C}$ for 15 days. For the calculation of the MPN of denitrifying bacteria / $1000 \mathrm{~mL}$, diphenylamine, which detects the presence of nitrates, was added to each culture tube. If a purple coloration is formed this test is negative. The Nessler reagent was used to verify the presence of ammonia in the medium; tubes that developed a yellow coloration were positive for denitrification. The production of nitrites was checked through the Griess reagent, this test was positive if a red coloration was formed. The results were analyzed using the MPN calculator version 3.1 software.

\subsection{Most probable number of nitrate-reducing bacteria}

Nitrite oxidizing bacteria were quantified in NOB medium (Suppl. 1) through the MPN technique in consecutive dilutions $\left(1 \times 10^{-1}, 1 \times 10^{-2}, 1 \times 10^{-3}, 1 \times 10^{-4}\right.$, and $\left.1 \times 10^{-5}\right)$, inoculated in the medium, and incubated at $30^{\circ} \mathrm{C}$ for 28 days, with five replicates per dilution (APHA, 2012). To observe the dissimilatory nitrate reduction capacity of the nitrite oxidizing bacteria in the positive and negative tubes of the five dilutions, aliquots were inoculated in a semisolid nitrate medium (18), incubated at $30^{\circ} \mathrm{C}$ for 20 days, and then assessed for the production of nitrites through the Griess reagent. The MPN mL ${ }^{-1}$ values of nitrate reducing bacteria were calculated using the NMP calculator version 3.1 software.

\subsection{Isolation of denitrifying bacteria}

Aliquots of minimal medium cultures, positive for denitrifying bacteria were streaked-out on solid minimal medium and sodium nitrate agar [16] (Suppl. 1). These cultures were incubated under aerobic and anaerobic conditions at $30^{\circ} \mathrm{C}$ from $10 \mathrm{~d}$ to $15 \mathrm{~d}$. Subsequently, macroscopic and microscopic descriptions were made with the isolated colonies. Colonies of Gram-negative bacilli and coccobacilli were further cultivated on King B agar (Merck, Germany) and pure colonies were evaluated with a traditional biochemical test battery, including positive fluorescence under UV light, oxide-fermentative tests for glucose, mannitol and arabinose, sulfate-indole-motility 
(SIM), urea, decarboxylation, and deamination of lysine and gelatin. Sporulated Gram-positive bacilli were further cultured in MMD and nitrate media and subjected to the biochemical tests of Vogues Proskauer, gelatin, oxidative fermentation of glucose, and arabinose [17].

\subsection{Quantification and isolation of total and fecal coliforms}

All water samples from the fish farm at Hato Laguna were membrane-filtered, plated on Chromocult agar (Merck, Germany), and employed in a MPN protocol for fecal coliforms in Verde Brila Broth [18] Subcultures were made from Chromocult colonies and positive Verde Brila Broth culture tubes in McConckey medium (Condalab, Spain), Hecktoen medium (Hispanlab S.A., Spain), and Eosin Methylene Blue (EMB) medium (Merck, Germany). These cultures were incubated between $25^{\circ} \mathrm{C}$ to $30^{\circ} \mathrm{C}$ and for up to 15 days, depending on the growth rate of the microbial isolates. Traditional biochemical tests were performed to determine the genera of the fecal coliforms.

\subsection{Statistical analysis}

The Kruskall Wallis, U-Mann Whitney test, and the Moses test were used to asses statistically significant differences in the MPN mL ${ }^{-1}$ values of the bacterial groups, the lake's physicochemical variables, and the concentration of nutrients among the lake's zones and sampling dates. Bonferroni corrections were applied $(p \leq 0.005)$. The Spearman correlation test was performed to assess the correlation between the abundances of denitrifying bacteria and the lake's physicochemical variables. The statistical software used for the analyses was IBM SPSS Statistics (Base 22.0, 2016).

\section{Results and Discussion}

\subsection{In situ Measurement of physicochemical variables}

The values of water $\mathrm{pH}$, alkalinity, electrical conductivity, dissolved oxygen (DO), oxygen saturation, and temperature showed statistically significant differences ( $p=0.049 ; p \leq$ $0.05, n=20$ ) and/or variability ( $p$ of Moses $=0.000$ ) among limnetic zones (Table 2).

The $\mathrm{pH}$ values of the water samples from Lake Tota revealed statistically significant differences $(p=0.049 ; p \leq 0.05, n=4)$. The water in zones with fish production activities had neutral $\mathrm{pH}$ (pH Hato Laguna: 6.8 to 7.2), whereas water in central limnetic zones had more alkaline values (Lago Chico: 7.9-8.1) during the months of low rainfall (Table 2).

Electrical conductivity was higher in all samples taken at Lago Grande El Túnel $\left(107.5 \mu \mathrm{S} \mathrm{cm}^{-1}\right.$ to $\left.288.7 \mu \mathrm{S} \mathrm{cm}^{-1}\right)$ than in samples taken at Custodia $\left(103.9 \mu \mathrm{S} \mathrm{cm}^{-1}\right.$ to $\left.108.5 \mu \mathrm{S} \mathrm{cm}^{-1}\right)$ and Hato Laguna (104.6 $\mu \mathrm{S} \mathrm{cm}^{-1}$ to $\left.109.4 \mu \mathrm{S} \mathrm{cm}^{-1}\right)$. This superior electrical conductivity value is indicative of pollution processes in aquatic environments with aquaculture practices [19].

Water dissolved oxygen and oxygen saturation during the months of August and September were lower in the two rainbow trout farming sites: Hato Laguna and El Túnel $\left(4.09 \mathrm{mg} \mathrm{L}^{-1}\right.$ to $\left.4.87 \mathrm{mg} \mathrm{L}^{-1}\right)(40.1 \%$ to $47.6 \%)$ compared to central limnetic areas $\left(4.92 \mathrm{mg} \mathrm{L}^{-1}\right.$ to $\left.5.10 \mathrm{mg} \mathrm{L}^{-1}\right)$ $(48.5 \%$ to $52.9 \%)$. Viet and colleagues [20] demonstrated a close relationship between DO variation and eutrophication in lakes. They argued that daily DO variation can be an important indicator of eutrophication and suggested it as the main parameter to assess water quality in eutrophied ecosystems. 
Table 2: Physicochemical variable values and nutrient concentrations recorded for the limnetic zones of Lake Tota, Boyacá - Colombia. Dur: Total hardness $\left(\mathrm{mg} \mathrm{L}^{-1}\right)$. Temp: Temperature $\left({ }^{\circ} \mathrm{C}\right)$. Cond: Electrical conductivity $\left(\mu \mathrm{S} \mathrm{cm}^{-1}\right)$. Ox: Oxygen saturation $(\%)$. TN: Total nitrogen $\left(\mathrm{mg} \mathrm{L}^{-1}\right)$. IN: inorganic nitrogen $\left(\mathrm{mg} \mathrm{L}^{-1}\right)$. DIP: Dissolved inorganic phosphorus (mg/L). TP: Total phosphorus $\left(\mathrm{mg} \mathrm{L}^{-1}\right)$. DIP: Dissolved inorganic phosphorus $\left(\mathrm{mg} \mathrm{L}^{-1}\right)$. 1, 2. July (two samples) 3. August. 4. September. * Statistically significant differences $(\alpha=0.05)$ $(p<0.05)$.

\begin{tabular}{|c|c|c|c|c|c|c|c|c|c|c|}
\hline Zone & Months & Dur & $\mathrm{ppH}$ & Temp & Cond & $\mathrm{Ox}$ & $\mathrm{TN}$ & DIN & $\mathrm{TP}$ & DIP \\
\hline \multirow{5}{*}{ Lago Chico Centro } & 1 & 40 & 7.9 & 14.2 & 104 & 44.3 & 1.8 & 1.7 & 0.055 & 0.072 \\
\hline & 2 & 50 & 7.6 & 14.7 & 105.1 & 52.9 & 1.8 & 1.6 & 0.072 & 0.058 \\
\hline & 3 & 35 & 7.9 & 14.3 & 138.5 & 48.6 & 1.9 & 2.4 & 0.072 & 0.086 \\
\hline & 4 & 45 & 8 & 14.8 & 104 & 46.4 & 1.8 & 1.6 & 0.066 & 0.056 \\
\hline & 1 & 40 & 7.8 & 14.5 & 105 & 50.2 & 1.8 & 1.7 & 0.067 & 0.057 \\
\hline \multirow{4}{*}{ Lago Chico Custodia } & 2 & 40 & 7.5 & 14.5 & 106.5 & 50.2 & 1.9 & 1.6 & 0.055 & 0.072 \\
\hline & 3 & 46 & 7.7 & 14.4 & 108.5 & 55 & 1.9 & 1.7 & 0.071 & 0.032 \\
\hline & 4 & 46 & 8 & 14.7 & 103.9 & 51.8 & 1.7 & 1.6 & 0.091 & 0.046 \\
\hline & 1 & 45 & 7.7 & 14.6 & 100.1 & 50.9 & 1.8 & 1.6 & 0.063 & 0.081 \\
\hline Lago & 2 & 45 & 7.5 & 14.5 & 105.8 & 53.1 & 1.8 & 1.6 & 0.059 & 0.052 \\
\hline \multirow[t]{3}{*}{ Grande Centro } & 3 & 45 & 7.4 & 14.4 & 109.7 & 48.5 & 1.9 & 1.6 & 0.09 & 0.061 \\
\hline & 4 & 41 & 8.1 & 14.4 & 109.9 & 49.2 & 1.7 & 1.6 & 0.078 & 0.051 \\
\hline & 1 & 50 & 7.5 & 14.6 & 106.7 & 55.6 & 1.9 & 1.7 & 0.073 & 0.063 \\
\hline Lago & 2 & 40 & 6.9 & 14.5 & 104.6 & 43.5 & 1.8 & 1.6 & 0.073 & 0.068 \\
\hline \multirow[t]{2}{*}{ Grande Hato Laguna } & 3 & 45 & 6.8 & 14.4 & 109.4 & 40.1 & 1.8 & 1.7 & 0.087 & 0.061 \\
\hline & 4 & 45 & 7.2 & 14.5 & 105.6 & 40.7 & 1.7 & 1.6 & 0.086 & 0.061 \\
\hline \multirow{4}{*}{ Lago Grande El Túnel } & 1 & 45 & 7.3 & 14.7 & 288.7 & 52.5 & 1.8 & 1.6 & 0.069 & 0.078 \\
\hline & 2 & 45 & 7.3 & 14.7 & 110.4 & 51.6 & 1.8 & 1.7 & 0.07 & 0.06 \\
\hline & 3 & 45 & 7.1 & 14.5 & 109.3 & 47.6 & 1.8 & 1.7 & 0.054 & 0.056 \\
\hline & 4 & 45 & 7.9 & 14.2 & 107.5 & 47.3 & 1.7 & 1.6 & 0.101 & 0.068 \\
\hline \multicolumn{11}{|c|}{$P$ Values } \\
\hline Between samplig zone & & 0.96 & $0.049 *$ & 0.97 & 0.29 & 0.39 & 0.9 & 0.6 & 0.5 & 0.52 \\
\hline Among samplig dates & & 0.96 & 0.11 & 0.22 & 0.19 & 0.37 & $0.010 *$ & $0.006^{*}$ & 0.12 & 0.22 \\
\hline
\end{tabular}

The concentrations of dissolved inorganic nitrogen (DIN) $(p=0.006 ; p \leq 0.05, n=5)$ and total nitrogen (TN) ( $p=0.01 ; p \leq 0.05, n=5)$ differed across months. These two variables had higher values in August (DIN: $(1.82 \pm 0.32) \mathrm{mg} \mathrm{L}^{-1}$; TN: $\left.(1.86 \pm 0.06) \mathrm{mg} \mathrm{L}^{-1}\right)$ than in July (DIN: $(1.63 \pm 0.02) \mathrm{mg} \mathrm{L}^{-1}$; TN: $\left.(1.80 \pm 0.03) \mathrm{mg} \mathrm{L}^{-1}\right)$, which was the rainiest month.

The concentrations of total phosphorus ( $\left.\mathrm{TP}=0.087 \mathrm{mg} \mathrm{L}^{-1} t o 0.101 \mathrm{mg} \mathrm{L}^{-1}\right)$ and dissolved inorganic phosphorus (DIP $=0.078 \mathrm{mg} \mathrm{L}^{-1}$ to $0.068 \mathrm{mg} \mathrm{L}^{-1}$ ) were higher in the water column of the lake areas with fish farming (Hato Laguna and El Túnel), compared to the limnetic areas of the center of the lake.

Likewise, during the rainy months the values of total nitrogen and dissolved inorganic nitrogen were higher in Hato Laguna in relation to the values observed in less polluted areas. An increase in $\mathrm{C}$ and $\mathrm{N}$ levels in aquatic environments with fish farming is a consequence of the excessive use of concentrates to feed the fish and their excreta, which are deposited in the lake sediments [21]

\subsection{Most probable numbers (MPN) for denitrifying and nitrate reducing bacteria}

There were no statistically significant differences between the abundances of denitrifying bacteria across months or among sampling zones ( $p=0.409 ; p \leq 0.05, n=4)$. However, denitrifying bacteria were more abundant in samples from Lago Grande Hato Laguna (Figure 2) than in samples 
from other lake zones from July to September $\left(4.2 \times 10^{4} \mathrm{MPN} \mathrm{mL}^{-1}\right.$ to $\left.2.4 \times 10^{6} \mathrm{MPN} \mathrm{mL}^{-1}\right)$. This is probably related to the high organic matter content and nitrogen input from fish farming activities.

According to a former study [14], Lake Tota is meso-oligotrophic, with high rates of eutrophication in zones such as El Túnel, where fish farming is practiced and where nutrient concentrations of $\mathrm{N}$ and $\mathrm{P}$ are high. Denitrifying bacteria become more abundant in lakes as trophic levels are added and anthropogenic contamination is accentuated. These two events elevate the concentration of nitrates and nitrites in fresh water ecosystems [4].

The MPN of nitrate reducing bacteria revealed statistically significant differences across months ( $p=0.026 ; p \leq 0.05, n=5$ ). Specifically, nitrate reducing bacteria numbers were lower in July $\left(7.4 \times 10^{3} \mathrm{MPN} \mathrm{mL}^{-1}\right.$ to $\left.3.5 \times 10^{4} \mathrm{MPN} \mathrm{mL}^{-1}\right)$ than in August and September $\left(2.7 \times 10^{4}\right.$ MPN mL ${ }^{-1}$ to $2.4 \times 10^{6} \mathrm{MPN} \mathrm{mL}^{-1}$ ) (Figure 2). The abundance of nitrate reducing bacteria for the sampled zone of Lago Grande was higher in the period with low rainfall $\left(4.6 \times 10^{5}\right.$ MPN mL ${ }^{-1}$ to $\left.2.4 \times 10^{6} \mathrm{MPN} \mathrm{mL}^{-1}\right)$, compared to the rainiest months $\left(1.1 \times 10^{4} \mathrm{MPN} \mathrm{mL}^{-1}\right.$ to $3.4 \times 10^{4} \mathrm{MPN} \mathrm{mL}^{-1}$ ).

The production of bacterial biomass is determined by an increase in the concentration of a limiting nutrient such as nitrate. This stimulates the growth and reproduction of the microbial communities that exploit the resource [6], namely denitrifying populations. In addition, increasing the trophic status in an ecosystem rises bacterial density is what we observed in the limnetic zones with fish farming activities in Lake Tota.

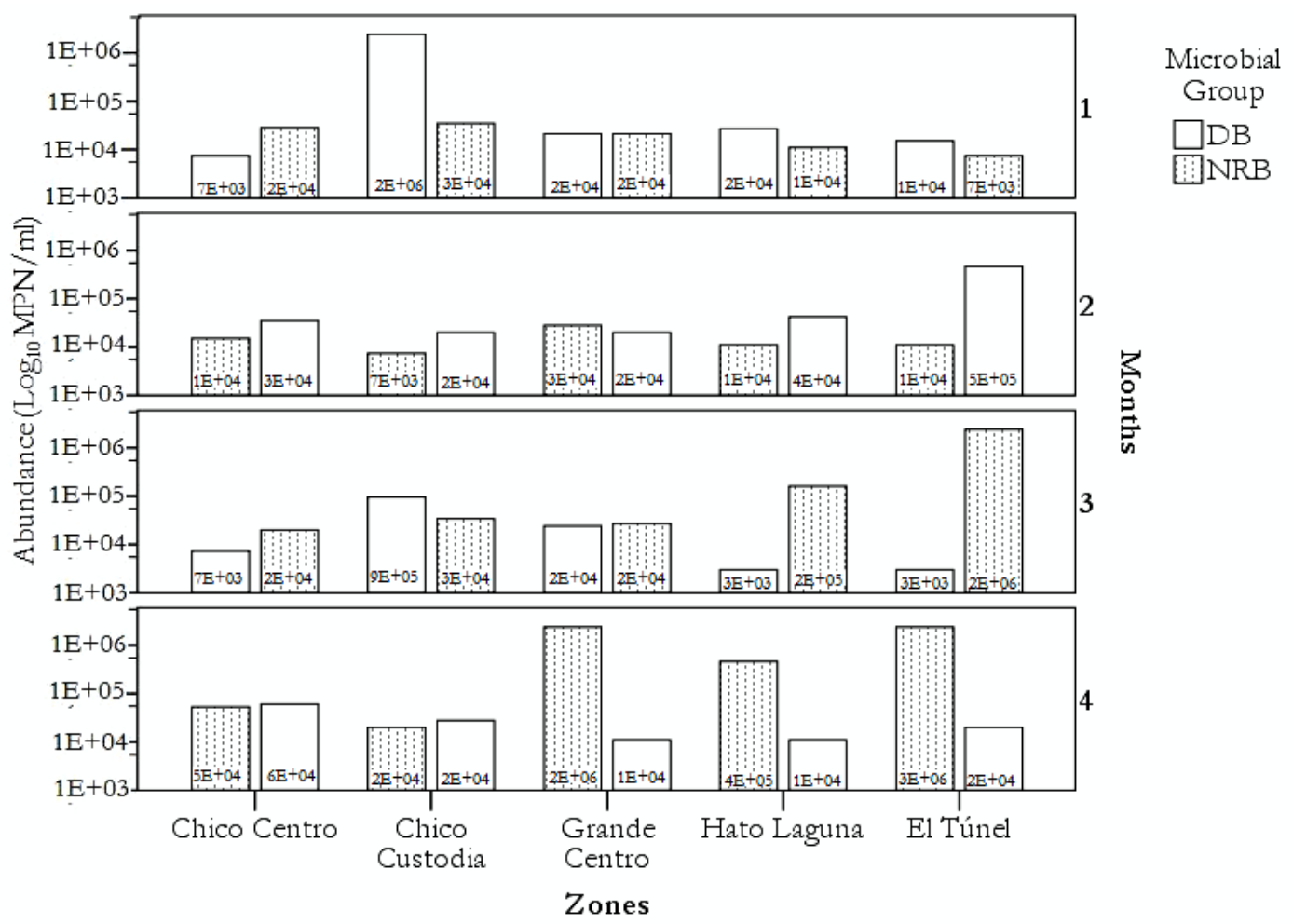

Figure 2: Abundance (expressed in term of $\mathrm{MPN} \mathrm{mL}^{-1}$ ) of cultured denitrifying bacteria (DB) and nitrate reducing bacteria (NRB) from the limnetic zones of Lake Tota in Boyacá, Colombia, during the rainy season. Months: July (1 and 2), August (3), and September (4). 


\subsection{Correlations between nutrients, physicochemical variables, and abundance of cultivable denitrifying bacteria}

In Lake Tota, $\mathrm{pH}$ was uncorrelated with the abundance of denitrifying bacteria. However, we observed that $\mathrm{pH}$ values tended to be neutral-to-acid in the fish farming areas of the Lake. A low $\mathrm{pH}$ can favor the increase of denitrifying bacteria populations, and an alkaline $\mathrm{pH}$ affects their growth [4]. Consequently, we observed a low abundance of denitrifying bacteria in the central limnetic zones of Lake Tota.

Denitrifying bacteria abundances were on average correlated with temperature only (Spearman's rho = $0.477, p=0.036, p \leq 0.05$ ). Temperature is a factor that positively influences denitrification rates, since it increases the growth of microbial populations in the summer or low rainfall periods [4]. Likewise, a correlation has been observed between temperature and abundance of denitrifying bacteria, assessed via a qPCR method, in a freshwater lakes and wetlands $[5,6,22]$. In these studies, the highest rates of denitrification, carried out by mesophilic microorganisms, were recorded in the summer and early autumn periods. Although denitrification can take place within a temperature range from $5{ }^{\circ} \mathrm{C}$ to $78{ }^{\circ} \mathrm{C}[5]$.

Oxygen saturation values were not significantly correlated with any of the other variables. However, it varied ( $p \leq 0.000$ ) between the Lago Chico and Lago Grande zones. This physicochemical condition could have influenced the high abundances of denitrifying bacteria recorded in the zones with fish farming, where oxygen is lower compared to the other zones.

In a recent study [23], higher denitrification potentials were identified in highly productive lakes, located at relatively low altitudes and small basins, with warmer sediments, and a high relative abundance of denitrification nitrite reductase genes. This indicates that denitrification could play a role important as a sink for enhanced deposition of atmospheric $\mathrm{N}$ [23].

Although no correlation was found between the abundance of denitrifying bacteria and dissolved oxygen and oxygen saturation, oxygen could have influenced the abundance of denitrifying bacteria in the rainbow trout zones, where its concentrations were low. Zhao and colleagues [4] also reported a negative correlation between the abundance of lake denitrifying bacteria and dissolved oxygen concentrations. At low concentrations, oxygen favors the presence of facultative anaerobic bacteria $[3,6]$.

We observed a direct average correlation between the concentrations of total phosphorus ( $r=$ $0.477, p=0.034, p \leq 0.05$ ) and the nitrate reducing bacteria populations from the sampling zones Chico Custodia, Grande Centro, and Hato Laguna. Sun et al. [24] described that phosphorus is used by denitrifying bacteria, under aerobic conditions. These bacteria can absorb short chain fatty acids and phosphates, which they store in polyhydroxyalkanoate inclusions or granules. Under anaerobic conditions denitrifying bacteria release fatty acids into the aquatic environment.

\subsection{Denitrifying bacteria}

Twelve bacterial isolates of denitrifying bacteria were cultivated, of which seven were identified as Bacillus spp.; two belonged in the order Actinomycetales, namely the genera Streptomyces spp. and Nocardia spp.; and two were Pseudomonas spp.

We observed the formation of translucent halos in nitrate medium inoculated with Bacillus spp. The diameter of the halos ranged between $0.5 \mathrm{~cm}$ to $1 \mathrm{~cm}$. The isolated bacteria are likely to be Bacillus megaterium, Bacillus lentus, Bacillus firmus, Bacillus licheniformes, and Bacillus psychrosaccharolyticus, with certainty percentages between $80 \%$ and $99 \%$. Two of 
these grew under anaerobic conditions. From water contaminated by nitrates we isolated mainly Bacillus cereus, Bacillus thuringensis, and Pseudomonas aeruginosa. From these three species, isolates with good nitrate degradation capabilities have been found under heterotrophic aerobic metabolism, at $30^{\circ} \mathrm{C}$ and a basic $\mathrm{pH}$ [13]. Also, the intestinal microbiota of the rainbow trout is mainly composed of bacteria from the phylum Firmicutes; when released by the fish in their feces, these bacteria can form denitrifying communities associated with the sediment [25]. We observed colonies growing in King B medium. Based on biochemical tests, we were able to identify them as Pseudomonas fluorescens and Pseudomonas stutzeri, with certainties of $90 \%$ and $89 \%$, respectively.

In environments contaminated by high nitrogen loads, denitrification is proposed as an important nitrate removal process, regulating the effects on phytoplankton growth [6,11]. Additionally, there is evidence that bacterial denitrification can act as a self-purifying mechanism for nitrate removal in high mountain lakes [26]. Some of the populations of the denitrifying bacteria of Lake Tota were heterotrophic, contributing to the decomposition of the organic matter from fish food in the water column and in the supernatant of the sediments [1].

Within the group of denitrifying bacteria of Lake Tota some genera were identified belonging to the families Pseudomonadaceae, Bacillaceae, and Enterobacteriaceae. These have been isolated with more frequency from lakes with increasing nitrate contamination levels [13, 26].

The most frequent bacterial genera isolated from rainbow trout farming zones in lakes are Pseudomonas and Bacillus [11,13]. These two genera are the most representative in denitrification process, can be heterotrophs, and can mineralize organic matter in such aquatic ecosystems [2]. Lv et al [11] isolated Pseudomonas spp. from the water column of a eutrophic lake and identified $P$. stutzeri and P. fluorescens. P. stutzeri performs a complete denitrification (from nitrates to gaseous nitrogen) under aerobic conditions and has been identified in fish tanks [6].

When the populations of Pseudomonas spp is high in fresh water, these bacteria can become opportunistic fish pathogens. For example, P. fluorescens is the most important species associated to fish pathology specially skin and fin diseases [27]. There are records of species such as Pseudomonas putida and Pseudomonas aeruginosa as opportunistic pathogens in farmed fish. In trout farms, $P$. fluorescens has been reported during every year regardless of the water temperature, infections that can cause mortality of about $100 \%$ in a rainbow trout population [27]. Equally, other species, such as P. putida and Pseudomonas luteola, make up the intestinal and internal organ microbiota, though some Pseudomoas species can cause a type of septicemia called "strawberry disease" in rainbow trout [27].

In the present study, other identified denitrifying genera were the Actinomycetes, Streptomyces and Nocardia. Both possess the ability to reduce nitrates to ammonium [3, 7]. Actinomycetes are characterized by their high capacity of mineralization of organic compounds. These bacteria can strengthen the immune system and resistance to diseases in fish by producing vitamins and antibiotics against pathogenic bacteria, shaping the intestinal microbiome of rainbow trout fish [25].

Isolates of Bacillus spp. were also obtained. Bacillus spp. are capable of performing denitrification in both aerobic and anaerobic conditions. Bacillus spp. may arise in the water column from the excreta of fish, as it makes up the intestinal microbiota of the fish [28], or from the sediments and soils of the lake, remaining in the water column for a short time. Bacillus spp. may reach the 
sediment mainly during rainfall periods, forming non-native populations in aquatic ecosystems. Bacillus populations are beneficial to fish health as they produce exopolysaccharides that possess antimicrobial activity against pathogens such as Vibrio spp. [29].

The species B. licheniformis, B. lentus, and B. firmus were isolated from Lake Tota, possessing aerobic and anaerobic denitrification capacities. The only prior study related to denitrifying bacteria involving Lake Tota was conducted in contaminated onion crop soils near the lake's littoral zone [30]. In this study B. licheniformis and P. stutzeri, were isolated from the limnetic zones of the lake. In addition, the same study [30] investigated in vitro denitrification, revealing an important biochemical characteristic of Bacillus spp. for possible uses in bioremediation [13]. Likewise, the isolation of aerobic denitrifying bacteria is important for bioaugmentation-based water treatment $[11,12,13]$.

All the isolates obtained possessed the capacity of aerobic denitrification and were heterotrophic. This is an important biochemical property of the selection of strains for the purification of the water column of lakes affected by rainbow trout farming, since these bacteria are known to facilitate the purification of the nitrate polluted surface water [11, 22].

\subsection{Coliforms}

Values greater than $1 \times 10^{4} \mathrm{CFU} \mathrm{mL} \mathrm{m}^{-1}$ and $1.1 \times 10^{4} \mathrm{MPN} \mathrm{mL}^{-1}$ of total coliforms were obtained in the fish farming zones of lake Tota. The following genera were identified: Escherichia spp., Klebsiella spp., Proteus spp., Edwardsiella spp., and Citrobacter spp. with certainties between $84 \%$ and $92 \%$.

Ribeiro et al [31] isolated enterohaemorrhagic $E$. coli from trout farming ponds. The presence of $E$. coli in the waters for fish production at Lake Tota is an indicator of persistent fecal contamination that may come from domestic wastewater, bovine feces, or fish feces. This situation poses a health risk to the final trout meat consumer, as it may be a vehicle for the transmission of enteric diarrheal diseases [29]. In ecosystems receiving contamination from sewage and freshwater habitats, total coliforms reduce nitrates to nitrites, thus participating in denitrification processes. The values of total coliforms in Lake Tota were acceptable according to existing national regulations for the development of the fish farming industry (Decree 1575 of 2007, Republic of Colombia).

Some heterotrophic bacteria that inhabit waters and sediments can cause diseases in fish [10]. Therefore, if the population density of these microbial groups increases considerably, fish health can be threatened, affecting fish farming in the zone. Furthermore, diseases produced by Vibrio spp can be generated due to excessive feeding, high fish density, increased number of microorganisms, such as coliforms and heterotrophs, as well as the loss of water quality due to excessive nutrients [32].

\section{Conclusions}

In Lake Tota, the populations of denitrifying bacteria were higher in the zones where rainbow trout farming is practiced than in the lake's central limnetic zones during the rainy months. Among the identified denitrifying bacteria, members of the genera Bacillus, Pseudomonas, Nocardia, Streptomyces, and Nitrobacter were identified. Total coliforms such as Escherichia spp., Klebsiella spp., Proteus spp., and Citrobacter spp. were also isolated from the lake. 
Slightly higher values of dissolved inorganic nitrogen, dissolved inorganic phosphorus, total phosphorus, electric conductivity, and lower concentrations of dissolved oxygen characterize the lake's limnetic zones where rainbow trout is farmed. These are indicators of a change in the oligotrophic state of the lake.

An elevated number of denitrifying bacteria in Lake Tota can increase the risk of disease development in fish by opportunistic microbial pathogens. High bacterial densities are indicative of changes in the trophic status in the limnetic areas of the lake due to inadequate fish production activities.

\section{Acknowledgements}

The work was funded by the initiative Capital Semilla No. 1, 2015, from the Research Directorate (DIN) at Universidad Pedagógica y Tecnológica de Colombia - UPTC. The authors acknowledge the the members the Unidad de Ecología de Ecosistemas Acuáticos (UDESA) research group at UPTC for their support in the field phase and the nutrient measurement tasks of the present study.

\section{Conflict of interest}

The authors have no conflict of interest to declare.

\section{References}

[1] Bertrand JC, Bonin P, Caumette P, Gattuso JP, Grégori G, Guyoneaud R, Le Roux X, Matheron R, Poly, F. Biogeochemical cycles. Environmental microbiology: fundamentals and applications. Springer Netherlands, 2015.

doi: 10.1007/978-94-017-9118-2_14

[2] Zumft WG. Cell biology and molecular basis of denitrification, Microbiology and molecular biology reviews, 61(4): 533-616, 1997.

Retrieved from: https://mmbr.asm.org/content/61/4/533.short

[3] Shapleigh JP. The Denitrifying Prokaryotes. The Prokaryotes. Springer, New York, USA, 2006.

doi: 10.1007/0-387-30742-7_23

[4] Zhao X, Wei Z, Zhao Y, Xi B, Wang X, Zhao T, Wei Y. Environmental factors influencing the distribution of ammonifying and denitrifying bacteria and water qualities in 10 lakes and reservoirs of the Northeast, China. Microbial Biotechnology, 8(3): 541-548, 2015.

doi: $10.1111 / 1751-7915.12260$

[5] Wei J, Li W, Cui L, Lei Y. Denitrifying bacterial communities in surface-flow constructed wetlands during different seasons: Characteristics and relationships with environment factors. PeerJ PrePrints, 5(1):e2848, 2017.

doi: 10.7287/peerj.preprints.2848v1 
[6] Zhang W, Gao Y, Yi N, Wang, C, Di P, Yan S. Variations in abundance and community composition of denitrifying bacteria during a cyanobacterial bloom in a eutrophic shallow lake in China. Journal of Freshwater Ecology, 32(1): 467-476, 2017.

doi: $10.1080 / 02705060.2017 .1323681$

[7] Shapleigh JP. Denitrifying prokaryotes. The prokaryotes. Springer Berlin Heidelberg, Germany, 2013.

doi: 10.1007/978-3-642-30141-4_71

[8] Hernández E, Aguirre N, Palacio J, Ramírez JJ, Duque SR, Guisande C, Mogollón M. (2013). Evaluación comparativa de algunas características limnológicas de seis ambientes leníticos de Colombia. Revista Facultad de Ingenieria, 69: 216-228, 2013.

Retrieved from: https://www.redalyc.org/pdf/430/43029812017.pdf

[9] Cardozo AYV, Gomes DF, Da Silva EM, Duque SRE, Rangel JC, Sifeddine A, Albuquerque ALS. (2014). Holocene paleolimnological reconstruction of a high altitude Colombian tropical lake. Palaeogeography, Palaeoclimatology, Palaeoecology, 415: 127-136, 2014.

doi: 10.1016/j.palaeo.2014.03.013

[10] Moriarty DJ. The role of microorganisms in aquaculture ponds. Aquaculture, 151(1-4): 333-349, 1997.

doi: 10.1016/S0044-8486(96)01487-1

[11] Lv P, Luo J, Zhuang X, Zhang D, Huang Z, Bai Z. Diversity of culturable aerobic denitrifying bacteria in the sediment, water and biofilms in Liangshui River of Beijing, China. Scientific reports, 7(1): 10032, 2017.

doi: $10.1038 / \mathrm{s} 41598-017-09556-9$

[12] Ni Z, Wu X, Li L, Lv Z, Zhang Z, Hao A, Li C. Pollution control and in situ bioremediation for lake aquaculture using an ecological dam. Journal of Cleaner Production, 172: 2256-2265, 2018.

doi: $10.1016 /$ j.jclepro.2017.11.185

[13] Wang P, Yuan Y, Li Q, Yang J, Zheng Y, He M. Isolation and immobilization of new aerobic denitrifying bacteria. International Biodeterioration \& Biodegradation, 76:12-7, 2013.

doi: 10.1016/j.ibiod.2012.06.008

[14] Unidad de Ecología en ecosistemas acuáticos (Udesa-Uptc), Corporación autónoma regional de Boyaca (Corpoboaycá). Efecto de la variabilidad climática de un ciclo anual sobre el flujo de nutrientes (, $\mathrm{N}$ y P), fuentes y biocaptación en el Lago de Tota. Informe final - Convenio 092 de 2015 Uptc \& Corpoboyacá. p. 41-55, 2015.

Retrieved from: http://www.corpoboyaca.gov.co/cms/wp-content/uploads/2016/10/ Flujo-Nutrientes-Tota.pdf

[15] Lachat Applications. Determination of Total Phosphorus in Manual Persulfate Digests. QuikChem. Lachat Instruments. Method 10;107-04-4-A, New York, USA 1-24, 2013. 
[16] Atlas RM. Handbook of Media for environmental Microbiology ( $2^{\text {nd }}$ edition). University of Louiswille. Kentucky, USA, 2005.

https://books.google.es/books?hl=es\&lr=\&id=TiV8ZOZ2bNkC\&oi=fnd\&pg=PP1\& $\mathrm{dq}=$ Atlas+RM.+Handbook+of + Media + for + environmental+Microbiology $+\& o t s=$ HtX3tMqNcL\&sig=szVDRUPZ7pE01LrBL3RsmeooIPY\#v=onepage \&q=Atlas\%20RM. $\% 20$ Handbook $\% 20 \mathrm{of} \% 20$ Media $\% 20$ for $\% 20$ environmental $\% 20$ Microbiology \&f=false

[17] Valls JS, Nacente RB. Handbook of Microbiological Culture Media. Scharlau Chemie, Barcelona, España 2011.

https://www.scharlabmagyarorszag.hu/katalogus/scharlau_mikrobiologiai_kezikonyv.pdf

[18] American Public Health Association (APHA), American Water Works Association (AWWA), Water Environment Federation (WEF). Standard Methods for examination of water and wastewater (22nd edition). Washington, D.C, USA 1323-1326, 2012. ISBN 978-087553-013-0

[19] Roldán G, Ramírez JJ. Fundamentos de Limnología neotropical. Editorial Universidad de Antioquia, Medellin Colombia 223-254, 2008.

http://www.ianas.com/docs/books/wbp14.pdf

[20] Viet ND, Bac NA, Huong HTT. Dissolved oxygen as an indicator for eutrophication in freshwater lakes. In Proceedings of international conference on environmental engineering and Management for Sustainable Development, Hanoi, Vietnam, 2016.

Retrieved from: https://www.researchgate.net/profile/Viet_Duc_Nguyen/publication/ 308991144_Dissolved_Oxygen_as_an_Indicator_for_Eutrophication_in_Freshwater_ Lakes

[21] Sipaúba-Tavares LH, Donadon ARV, Milan, RN. Water quality and plankton populations in an earthen polyculture pond. Brazilian Journal of Biology, 71(4): 845-855, 2011.

doi: $10.1590 / S 1519-69842011000500005$

[22] Wang F, Zhao Y, Shulian X, Li, J. Implication of nitrifying and denitrifying bacteria for nitrogen removal in a shallow lake. CLEAN: Soil, Air, Water, 45 (4): 1500319, 2017.

doi: $10.1002 /$ clen.201500319.

[23] Palacin-Lizarbe C, Camarero L, Hallin S, Jones CM, Catalan J. Denitrification rates in lake sediments of mountains affected by high atmospheric nitrogen deposition. Scientific reports, 10(1), 1-9, 2020.

doi: $10.5061 /$ dryad.j6q573n95.

[24] Sun L, Zhao X, Zhang H, Zhang Y. Biological characteristics of a denitrifying phosphorusaccumulating bacterium. Ecological Engineering, 81:82-88, 2015.

doi: 10.1016/j.ecoleng.2015.04.030

[25] Ceppa F, Faccenda F, De Filippo C, Albanese D, Pindo M, Martelli R, Parisi G. Influence of essential oils in diet and life-stage on gut microbiota and fillet quality of rainbow trout (Oncorhynchus mykiss). International Journal of Food Sciences \& Nutrition, 69(3):318-333, 2018. 
doi: 10.1080/09637486.2017.1370699

[26] Castellano-Hinojosa A, Correa-Galeote D, Carrillo P , Bedmar EJ, Medina-Sánchez JM. Denitrification and biodiversity of denitrifiers in a high-mountain Mediterranean lake. Frontiers in microbiology, 8 (1911): 1-12, 2017.

doi: 10.3389/fmicb.2017.01911

[27] Pkala-Safiska A. Contemporary threats of bacterial infections in freshwater fish. Journal of veterinary research, 62(3): 261-267, 2018.

doi: $10.2478 /$ jvetres-2018-0037

[28] Parshukov AN, Kashinskaya EN, Simonov EP, Hlunov OV, Izvekova GI, Andree KB, Solovyev MM. Variations of the intestinal gut microbiota of farmed rainbow trout, Oncorhynchus mykiss (Walbaum), depending on the infection status of the fish. Journal Of Applied Microbiology, 127(2):379-395, 2019.

doi: doi: $10.1111 /$ jam.14302

[29] Barman P, Bandyopadhyay P, Mondal KC, Das Mohapatra PK. Water quality improvement of Penaeus monodon culture pond for higher productivity through bioremediation. Acta Biologica Szegediensis, 59: 169-177, 2015.

Retrieved from: http://abs.bibl.u-szeged.hu/index.php/abs/article/view/2879

[30] Benavides-López de Mesa, JL, Quintero GM, Ostos-Ortiz OL. Aislamiento e identificación de diez cepas bacterianas desnitrificantes a partir de un suelo agrícola contaminado con abonos nitrogenados proveniente de una finca productora de cebolla en la Laguna de Tota, Boyacá, Colombia. Nova, 4(6): 50-54, 2006.

doi: $10.22490 / 24629448.360$

[31] Ribeiro LF, Barbosa MMC, Rezende Pinto F, Guariz CSL, Maluta RP, Rossi JR, Amaral LA. Shiga toxigenic and enteropathogenic Escherichia coli in water and fish from paytofish ponds. Letters in applied microbiology, 62(3): 216-220, 2016.

doi: 10.1111/lam.12536

[32] Tey YH, Jong KJ, Fen SY, Wong, HC. Occurrence of Vibrio parahaemolyticus, Vibrio cholerae, and Vibrio vulnificus in the aquacultural environments of Taiwan. Journal of food protection, 78(5): 969-976, 2015.

doi: 10.4315/0362-028X.JFP-14-405 


\section{Bacterias denitrificantes en la zona limnética del Lago de Tota, Colombia}

Resumen: El objetivo de este estudio fue aislar y determinar la identidad de las bacterias denitrificantes de áreas limnéticas de Lago de Tota (Andes Colombianos) con y sin actividades de producción de trucha arcoíris. Se examinaron las relaciones entre los factores fisicoquímicos del lago (oxígeno, nitrógeno y contenido de fósforo) y dos comunidades bacterianas (bacterias denitrificantes y coliformes). Se tomaron muestras de agua a $20 \mathrm{~m}$ bajo la superficie entre julio y septiembre en cinco zonas limnéticas; dos de ellas estaban cerca de áreas de cría de trucha arcoíris. En cada zona se midieron las concentraciones de oxígeno, nitrógeno y fósforo. Para identificar y cuantificar la abundancia de bacterias, se usó la técnica de Número Más Probable (NMP), utilizando medio mínimo para bacterias denitrificantes y medio para bacterias nitrato-reductoras (BNR). Se encontró un número mayor de bacterias denitrificantes en las zonas de cría de peces, identificadas como los géneros Bacillus, Pseudomonas, Nocardia y Streptomyces. El número de bacterias nitrato-reductoras reveló diferencias estadísticamente significativas a lo largo del periodo de muestreo, aumentando de julio a septiembre, y se relacionó con una disminución en la precipitación. La densidad de BNR y el fósforo toral estuvieron directamente correlacionados directamente. Altas densidades de bacterias denitrificantes y de coliformes son indicativo de cambios de estados oligótrofico a eutróficos en las áreas limnéticas estudiadas.

Palabras Clave: Bacterias denitrificantes; eutroficación; criaderos de peces; lagos de agua dulce; contaminación acuática.

\section{Bacterias denitrificantes en la zona limnética del Lago de Tota, Colombia}

Resumo: O objetivo de este estudo foi isolar e determinar a identidade das bactérias desnitrificantes de áreas limnética do Lago de Tota (Andes Colombiano) com e sem atividades de produção de truta arco-íris. Examinaram-se as relações entre os fatores físico-químicos do lago (oxigênio, nitrogênio e conteúdo de fósforo) e duas comunidades bacterianas (bactérias desnitrificantes e coliformes). Tomaram-se amostras de água a $20 \mathrm{~m}$ de profundidade entre julho e setembro em cinco zonas limnética; duas delas próximas a área de criação de truta arco-íris. Em cada zona se mediram as concentrações de oxigênio, nitrogênio e fósforo. Para identificar e quantificar a abundância de bactérias, se utilizou a técnica de Número Mais Provável (NMP), usando meio mínimo para bactérias desnitrificantes e meio para bactérias nitrato-redutoras (BNR). Se encontrou um número maior de bactérias desnitrificantes nas zonas de criação de peixes, identificadas como sendo dos géneros Bacillus, Pseudomonas, Nocardia e Streptomyces. O número de bactérias nitrato-redutoras revelou diferenças estatisticamente significativas ao longo do período de amostragem, aumentando de julho a setembro, o qual foi relacionado a uma diminuição da precipitação. A densidade de BNR e fósforo total estiveram diretamente correlacionados. Altas densidades de bactérias desnitrificantes e de coliformes são indicativos de alterações de estado oligotrófico à eutrófico nas áreas limnética estudadas.

Palavras-chave: Bactérias desnitrificantes; eutroficação; criadouro de peixes; lagos de água doce; contaminação aquática 


\section{Julián Esteban Másmela Mendoza}

Biologist- Universidad Pedagógica y Tecnológica de Colombia. Master in Biology- Universidad de Antioquia, Colombia. His research interests are in agricultural microbiology, aquatic microbiology, and microbial ecology.

ORCID: 0000-0002-6019-1449

\section{Luz Marina Lizarazo Forero}

Bacteriologist and Clinical Laboratory-Universidad Industrial de Santander, Colombia. Master in Microbiology-Pontificia Universidad Javeriana, Colombia. PhD in Biology-University of Alicante-Spain. Postdoctoral in Interaction Plant-Microorganisms-Experimental Station of Zaidín-Spain. Associate Professor, Coordinator of the Environmental Biology Research Group, attached to the Faculty of Sciences, School of

Biology-Pedagogical and Technological University of Colombia-Tunja- Boyacá Headquarters. Junior Researcher.

ORCID: 0000-0002-7849-7876 